\title{
Teachers' Conception and Difficulties in Doing Action Research
}

\author{
Darin Jan Tindowen ${ }^{1, *}$, Joy Guzman², Domer Macanang ${ }^{3}$ \\ ${ }^{1}$ Center for Social Innovation, Local Knowledge and Educational Research, University of Saint Louis, Tuguegarao City, Philippines \\ ${ }^{2}$ Department of Junior High School, University of Saint Louis, Tuguegarao City, Philippines \\ ${ }^{3}$ School of Education, Arts, and Sciences, University of Saint Louis, Tuguegarao City, Philippines
}

Copyright $\bigcirc 2019$ by authors, all rights reserved. Authors agree that this article remains permanently open access under the terms of the Creative Commons Attribution License 4.0 International License

\begin{abstract}
This study was conducted to describe the conceptions and difficulties of Junior High School teachers in the conduct of action research. A combination of quantitative and qualitative types of research was utilized in the study involving 60 teachers in the Junior High School department. The results reveal that action research is a valuable tool for teachers to improve teaching and learning process, to increase pedagogical and instructional knowledge, and to positively impact students' learning. Furthermore, teachers have difficulties in the conduct of action research especially literature search, presentation and publication of results, and data collection. Finally, four major themes emerged as the major issues and challenges of teachers in the conduct of action research, which are additional workload and burden in the part of the teacher, writing anxiety, lack of time, and inadequate knowledge in the conduct of action research.
\end{abstract}

Keywords Action Research, Conceptions and Difficulties, Junior High School Teachers

\section{Introduction}

The educational system of the Philippines is rapidly evolving due to many factors such as ASEAN integration, global competitiveness, globalization, integration of ICT in teaching and other important internal and external factors. With the implementation of the new K-12 program of the Department of Education across all Basic Education institutions in the Philippines, some key impetus should be considered such as evidence-based policy, better student achievement, enhancement of curriculum, instruction, and assessment, teacher quality and teacher professionalism (Abaya, 2017; Tindowen, Bassig, \& Cagurangan, 2017). With these, many important factors should be considered for basic education institutions to cope with the demands of the fast-changing world. And one of these factors is the inclusion of action research as a major function of a teacher in the $21^{\text {st }}$ century (Chou, 2011; Hazelton \& Haigh, 2010). It is then imperative for teachers to embrace action research in their professional lives to foster a culture of research among schools to improve educational outcomes for local and global competitiveness.

Action research is a process of systematic, reflective inquiry to improve educational practices or resolve problems in any operating unit such as in the school, classroom, and office (Department of Education, 2017). Furthermore, action research is related to ideas of reflective teacher and teacher as researcher. Action research involves taking a self-reflective critical and systematic approach to exploring one's teaching contexts, and seeks to intervene in a deliberate way in the problematic situation to bring about changes and even better improvement in practice. Also, action research is in the hands of teachers and reflexivity, action, and transformation are embedded in the process of teachers' examining their own teaching practices (Burns, 2014). Many studies and previous literature had proven the positive outcomes of action research to many academic aspects, such as improvement of teaching and learning, reflection of teachers' practice, and professional growth of teachers. It most especially leads to positive educational outcomes of students such as improved academic performance, promotion of positive behavior and values, and enhancement of life and survival skills (Burns, 2011; Dick, 2006; Taylor \& Medina, 2013). In fact, the Department of Education implemented and initiated many activities and programs for the institutionalization of action research in the Basic Education. Some of the major shifts and initiatives of the department about action research are the implementation of the DepEd No. 24 series of 2010 or the Basic Education Research Fund, DepEd No. 13 Series of 2013 or the Establishment of a Policy Development Process at the Department of Education, DepEd No. 13 series of 2015 or the Revised Guidelines for the Basic Education Research Fund, DepEd No. 4 Series of 2016 or the Amendment to DepEd No. 43 Series of 2015, and 
DepEd No. 39 series of 2016 or the Adoption of the Basic Education Research Agenda.

However, despite the institutionalization of research in the basic education and many initiatives and programs of the Department of Education, the research productivity of teachers is still low (Vinluan, 2011; Mapa, 2017; Kiley \& Mullins, 2005). In fact, results of previous studies revealed that teachers in the basic education such as in the junior high school are still in the adjustment phase in embracing action research as part of their educational culture (Salazar-Clemena, 2006; Hirsch, 2005). In addition, many studies conducted focused on the status of research productivity of teachers' action research (Kusure, Mutanda, Maware, \& Dhliwayo, 2006; Chen, Nixon, Gupta, \& Hoshower, 2010; Arnold, 2008), but limited studies were conducted to look into the root cause of this low productivity of teachers, such as looking on their conceptions and difficulties in conducting action research (Inanc \& Tuncer, 2011; Ynalvez \& Shrum, 2011).

This study was conducted to describe the conceptions of Junior High School teachers towards action research and exploring their difficulties and challenges in conducting action researches. As the Head of the Educational Research across all the levels in the university, the researcher observed that the productivity of teachers in the Junior High School is low. With this study, the result will address the issue on the root cause of this low productivity of teachers in doing action research. And with the result, this will serve as a basis for the school administration in coming up with intervention program to enhance and improve the research productivity of Junior High School teachers.

\subsection{Action Research in the Basic Education}

Action research in education has gained increasing attention in the past 20 years especially among First world countries, and even in developing countries such as in the Philippines. It is believed that action research originated from an American Psychologist Kurt Lewin in the mid-1940s (Efron \& Ravid, 2013). Lewin described action research proceeding in a spiral of steps, each of which is composed of planning, action and the evaluation of the result of action (Lewin, 1946). He further stressed that action research is a form of experimental inquiry based upon the groups experiencing problems. What is basic to Lewin's model is a view of research composed of action cycles including analysis, fact-finding, conceptualization, planning, implementation and evaluation of action (McKernan, 1991). Moreover, action research is a form of collective self-reflective enquiry undertaken by participants in social situations in order to improve the rationality and justice of their own social or educational practices, as well as their understanding of these practices and the situations in which these practices are carried out (Kemmis \& McTaggart, 1988).
Action research as a methodology surfaced in response to the growing need for more relevant and practical knowledge in the social sciences as it bridged the gap between academic research and day-to-day applications (Nolen \& Putten, 2007; de Zeeuw, 2003). Today, action research plays a very vital role in all basic education institutions in the Philippines as it is deemed necessary in improving educational outcomes and also contributes towards global competitiveness.

Many studies argued the importance of action research in the educational setting especially in the basic education sectors.

Brookmyer (2007) revealed in his study that action research is an important information base for reflective practice, a vital foundation on which to develop professionalism. It provides valuable knowledge for classroom practice and provides a context for the transformation of practice. Furthermore, one important function of action research is that it fills the gaps between theory and practice (Chevalier \& Buckles, 2019; Edwards-Groves \& Kemmis, 2016). More importantly, action research tries to solve an immediate educational problem and issues such as pedagogy, classroom management, teaching and learning, assessment and instructional strategy, community and school relations among others (Mertler, 2016; Chevalier \& Buckles, 2019; Ulla, 2018)

\subsection{Action Research Models}

It has been stressed that action research is a process of systematic inquiry that enables people to find effective solutions to real problems encountered in daily life (Lewin, 1946; Stringer, 2008). Action research is termed into different concepts such as action science, community-based participatory research, action learning, appreciative inquiry, living theory, participatory action leadership action research and participatory action research (Morales, et. al., 2016). There are major theoretical models of action research that are being used in the educational settings.

Calhoun's action research approach focuses on the school-wide or district-wide pursuit of student learning goals. It emphasizes using action research to change the way the organization works so that teachers and students and staff learning continually and pour information from the external knowledge base into the collective study and action-taking process (Calhoun, 1994). Meanwhile, McNiff (1984) also presented an action research model, which is a generative model. His model is a dynamic model, which is a framework that allowed the flexibility to accommodate problems as and when they arose. Furthermore, the generative capacity of action research singles out from static discipline approaches; approaches that tend to a rigid theory that requires reality to be confined within its stasis and is therefore not adequate to 
deal with explanations of individuals' lives. Another action model proposed by Cardno and Piggot-Irvine (1996) stipulates that action research is an applied approach to resolving organizational problems collaboratively. The model involves three major phases or cycles of activity. Each cyclic phase incorporates steps of planning, acting, observing and reflecting. Furthermore, action research is an educative and developmental process and is effective when reflective practice is data-based and multiple perspectives are acknowledged and critique is based on explicit norms and theories of action.

\section{Methods}

This study utilized both quantitative and qualitative types of research. The respondents of the study are the Junior High School Teachers of a Catholic Higher Education Institution in Northern Philippines in the School year 2017-2018. Total enumeration was utilized in the study. All 65 teachers were given a questionnaire; however, only 60 questionnaires were retrieved. Among the respondents of the study, majority of the teachers are teaching in less than five years and possessed bachelor's degree as their highest educational attainment. It is important to note that almost all of the teachers did not complete any action research.

\subsection{Quantitative Instrument}

The study utilized a standard questionnaire developed by Morales, et. al. (2016) to examine the conception and difficulties of teachers in doing action research. The said tool consists of 13 items divided into two indicators which are Conceptions on the outcomes of action research (5 items) and Difficulties in conducting action research (8 items).

\subsection{Qualitative Instrument}

The study also utilized an open-ended questionnaire in order to explore the issues and challenges of Junior High School teachers in the conduct of action research.

\subsection{Data Analysis}

The data were analyzed using mean and median to describe the conceptions of the respondents on the outcome of action research and the difficulties of teachers in the conduct of action research. For the qualitative data, thematic analysis was used to explore the issues and challenges experienced by teachers in the conduct of action research.

\section{Results and Discussion}

\subsection{Conceptions on the Outcomes of Action Research}

Table 1 presents the conceptions of Junior High School teachers on the outcomes of action research. It can be shown in that table that teachers agree to all the items regarding the outcomes of action research. Teachers of the junior high school agree that action research is a valuable way to improve teaching and learning. This means that teachers view action research as an important tool in the successful delivery of instruction in the classroom that will lead to positive learning outcomes. Many educational researchers and theorists had defined action research as a tool in improving teaching and learning (Halim, Buang, \& Meerah, 2010; McIntosh, 2010). Hence, teachers of the Junior High School affirmed this claim on the role of action research in the classroom.

Table 1. Conceptions of Junior High School Teachers on the Outcomes of Action Research

\begin{tabular}{|ll|l|l|l|}
\hline \multicolumn{2}{|c|}{ Items } & Mean & Median & $\begin{array}{l}\text { Qualitative } \\
\text { Description }\end{array}$ \\
\hline 1. $\begin{array}{l}\text { Action research is a } \\
\text { valuable way to } \\
\text { improve teaching and } \\
\text { learning. }\end{array}$ & 4.15 & 3.00 & Agree \\
\hline 2. & $\begin{array}{l}\text { Action research is a } \\
\text { valuable way to develop } \\
\text { knowledge as a teacher. }\end{array}$ & 4.00 & 3.00 & Agree \\
\hline $3 . \quad \begin{array}{l}\text { Action learning is } \\
\text { important to the } \\
\text { teaching and learning } \\
\text { process for my students. }\end{array}$ & 4.15 & 3.00 & Agree \\
\hline 4. & $\begin{array}{l}\text { Action research project } \\
\text { will positively impact } \\
\text { my students'learning }\end{array}$ & 3.85 & 3.00 & Agree \\
\hline 5. $\begin{array}{l}\text { I view myself as a } \\
\text { teacher-researcher. }\end{array}$ & 3.15 & 3.00 & Agree \\
\hline
\end{tabular}

Moreover, teachers also agreed that action research is a valuable way to develop knowledge as a teacher. The result would explain the role of action research in the enhancement of pedagogical and instructional knowledge of teachers as a way of professional growth. Previous studies conducted stressed that action research is vital in the delivery of content lessons through research since teachers are given more opportunity to expand their content knowledge and even pedagogies (Chen \& Kessler, 2013; Ozer, Ritterman, \& Wanis, 2010; Zhou, 2012).

Meanwhile, teachers also agreed that action research is important to the teaching and learning process for the students. This means that even in the utilization of action research, teachers always consider students' attitude and academic performance. This would also entail that the main goal of action research is geared towards students' improvement in the academic setting and in other aspects (Krell \& Dana, 2012; Mamlok-Naaman \& Eilks, 2012).

In addition, teachers also agreed that action research project would positively impact students' learning. This means that action research should always provide positive learning environment for students. This could also 
influence students' learning since teachers will have an opportunity to look on a variety of teaching strategies that will cater to the needs of the learners (Clarke, \& Fournillier, 2012).

Finally, teachers also agreed that they view themselves as teacher-researchers. This could be attributed to the fact that in the $21^{\text {st }}$ century learning landscape, teachers are not only confined in the four corners of the classroom for instructional delivery, but also need to fulfill one of its functions, which is on research (Hayes, 2011; Winch, Oancea \& Orchard, 2015). The Department of Education already mandated teachers to do action research and also one of the requirements for their promotion since teachers should be knowledge generators, and not just knowledge borrowers.

\subsection{Difficulties of Junior High School Teachers in Conducting Action Research}

Table 2 presents the difficulty and non-difficulty of Junior High School teachers in conducting action research. It can be gleaned in the table that teachers of the Junior High School do not experience any difficulty in organization and writing findings and using technology in literature search, data presentation, and bibliographical entries. This means that Junior High school teachers are already equipped with the proper knowledge and skill in the writing research papers and reports. They already know how to organize their thoughts and have the ability to put the results into writing. Furthermore, Junior High School teachers are already knowledgeable with the use of different technologies in doing research. This can be attributed to the fact that there is already a substantial number of easy-to-use research software that is freely available and can be downloaded in the internet (Sales Traver, \& García, 2011; Strambler, \& McKown, 2013). Also, the university library has enough research materials and electronic references and software that will help teachers in the conduct of their research.

Meanwhile, it is also presented in the table that still many teachers are experiencing difficulties in the conduct of action research from the identification of their research problem until the publication of the results of the research. The results may imply that teachers do not yet possess the required skills in writing action researches. Among the items in the conduct of action research, searching for relevant literature to the chosen topic is considered as the major difficulty of teachers. Literature review is one of the most critical parts of a research paper. It provides the theoretical background of the study and serves as the links between the proposed study and what has already been studied, and more importantly, it integrates the research findings into the existing body of knowledge (Russ \& Bruce, 2012; Cain, 2011). With the result, it can be stressed that teachers do not yet possess the skill of looking for appropriate related studies and literature that are suitable to the current study. The findings of the study affirmed the results of previous studies that indeed, literature review is the most difficult part of a research paper according to teachers (Fieldman \& Weiss, 2010; Mcniff, 2016; Riel, 2010).

Table 2. Difficulties of Junior High School Teachers in Conducting Action Research

\begin{tabular}{|c|c|c|c|c|}
\hline \multicolumn{2}{|r|}{ Items } & Mean & Median & Qualitative Description \\
\hline 1. & $\begin{array}{l}\text { Identifying issues and problems to be investigated by } \\
\text { action research. }\end{array}$ & 3.15 & 3.00 & Difficulty \\
\hline 2. & Searching for relevant literature to the chosen research & 4.66 & 3.00 & Difficulty \\
\hline 3. & $\begin{array}{l}\text { Developing the processes of how to do research and } \\
\text { collect evidence. }\end{array}$ & 4.00 & 3.00 & Difficulty \\
\hline 4. & Analyzing quantitative data & 3.15 & 3.00 & Difficulty \\
\hline 5. & Analyzing qualitative data & 3.66 & 3.00 & Difficulty \\
\hline 6. & Organizing and writing the findings & 2.85 & 3.00 & Non-Difficulty \\
\hline 7. & $\begin{array}{l}\text { Making a relevant presentation on the project and write } \\
\text { article for publication }\end{array}$ & 4.30 & 3.00 & Difficulty \\
\hline 8. & $\begin{array}{l}\text { Using technology in: } \\
\text { a. } \quad \text { Literature Search } \\
\text { b. } \quad \text { Data presentation } \\
\text { c. } \quad \text { Statistical analysis } \\
\text { d. } \quad \text { Bibliographical entries }\end{array}$ & $\begin{array}{l}2.15 \\
2.15 \\
3.15 \\
2.00\end{array}$ & $\begin{array}{l}3.00 \\
3.00 \\
3.00 \\
3.00\end{array}$ & $\begin{array}{l}\text { Non-Difficulty } \\
\text { Non-Difficulty } \\
\text { Difficulty } \\
\text { Non-Difficulty }\end{array}$ \\
\hline
\end{tabular}




\subsection{Issues and Challenges of Teachers in the Conduct of Action Research}

Table 3 presents the different issues and challenges of Junior High School teachers in the conduct of action research. Based on the responses of the respondents, four themes emerged as the major issues and challenges of teachers in the conduct of research, namely: additional workload and burden in the part of the teacher, writing anxiety, lack of time, and inadequate knowledge regarding the conduct of action research.

Table 3. Issues and Challenges of Junior High School Teachers in the Conduct of Action Research

\begin{tabular}{|l|c|c|c|}
\hline \multicolumn{1}{|c|}{ Issues and Challenges } & Frequency & Percentage & Rank \\
\hline $\begin{array}{l}\text { Additional workload and } \\
\text { burden in the part of the } \\
\text { teacher }\end{array}$ & 35 & 58.33 & 2 \\
\hline Writing Anxiety & 30 & 50.00 & 3 \\
\hline Lack of Time & 42 & 70.00 & 1 \\
\hline $\begin{array}{l}\text { Inadequate knowledge } \\
\text { regarding the conduct of } \\
\text { action research }\end{array}$ & 25 & 41.67 & 4 \\
\hline
\end{tabular}

\subsection{Additional Workload and Burden in the Part of the Teacher}

One of the major themes that were transcribed in the study is that teachers are having difficulty in doing action research since this serves as an additional workload and burden on their part. Specifically, teachers are experiencing workload problems since this is a stressful task, overlapping of activities, and will experience sleepless nights and will eventually lead to stress. Some of their verbalizations are as follows:

T12: "As much as I would like to conduct action research, we have a lot of things to do, many papers to be submitted and many deadlines to meet."

T34: "For me, I know how important action research is in the classroom. However, sometimes, doing action research is a burden on my part because you know our workload in the high school. We need to satisfy many requirements not only in the classroom but also in other things. Hence, we do not have any time doing action research."

T19: "Working in high school is very stressful. You need to think of many concerns such as in the classroom, the attitudes of students that sometimes, I already forgot to do other things such as action research. Doing action research is stressful because I only do this when I have a vacant time and sometimes this is my least priority because many activities sometimes are overlapping.

\subsection{Writing Anxiety}

Another theme that was deduced from the responses of teachers is that they encounter issues regarding the conduct of action research and they have writing anxiety.
Specifically, teachers have fear in analyzing data and some have problems on their grammar. Some of their verbalization is as follows:

T18: "Honestly speaking, I do not have the skill in writing most especially in writing research. I am afraid that when I do research, I am afraid that my paper will be rejected because of my writing ability."

T20: "One of my greatest fears is that I have problems regarding grammar. And I do not want to be embarrassed because of that. Definitely, many teachers and students will read my paper and I am afraid that many grammatical lapses will be read by my readers."

\subsection{Lack of Time}

Most of the respondents stressed that their major issue and challenge in the conduct of action research is that they lack time. This means that teachers do not have available time to conduct an action research. Some of their verbalizations are as follows:

T45: "I do not have any time in doing action research. When I'm done with my school requirements, I need also to take care of my children and my family."

T10: "I really love to do action research, but time will not permit me to do so"

T55: "I hope the school will also consider our time because 24 hours is not enough to finish all the requirements needed by the school. During weekends, I do not also have time doing action research because I am also busy for my master's degree."

\subsection{Inadequate Knowledge Regarding the Conduct of Action Research}

Finally, the last theme that was transcribed in the responses of teachers regarding their issues and challenges in the conduct of action research is that they have an inadequate knowledge about the conduct of action research. The results further mean that teachers have difficulty in data gathering and also the process of writing the full action research. Some of their verbalization is as follows:

T60: "I do not really know how to write a research paper, especially action research. I was not really oriented since then on the ways in writing action researches."

T21: "I am not familiar with action research. I do not have enough knowledge regarding the conduct of action research. All I thought that in high school, what we just do is to teach. But I was surprised that we also need to do action research."

\section{Conclusions}

The study concludes that action research is a valuable tool for teachers to improve teaching and learning process, to increase pedagogical and instructional knowledge, and positively impact students' learning. Furthermore, teachers 
have difficulties in the conduct of action research especially literature search, presentation and publication of results, and data collection. Finally, four major themes emerged as the major issues and challenges of teachers in the conduct of action research, which are additional workload and burden in the part of the teacher, writing anxiety, lack of time, and inadequate knowledge in the conduct of action research.

The results of the study have strong implications to the educational practice. First, the study provides strong points on the idea that action research fills the gap between theory and practice. Since, teachers believed that action research improves teaching and learning process, then it can be stressed that conducting action research may provide beneficial and enabling experiences for teachers to transform and create positive classroom environments that are based on theories and concepts. Hence, it is highly recommended that school administrators must encourage and support their teachers in doing action research by designing an institutional action research policy for the faculty. The institutional action research policy may include processes and policies in the conduct of action research. More importantly, rewards and remunerations must also be included in the policy to motivate teachers in doing action research. Initiatives and programs that will sustain and enhance teachers' motivation to engage in doing action research must also be considered.

Second, the study also revealed that action research is indeed beneficial in all aspects and that action research can enhance both teachers' practice and students' learning. It was evident that there are amounts of difficulty of teachers in doing action research. The results still revealed that teachers have the capacity to transcend themselves through self-improvement and also continuous professional development. Furthermore, though Junior High School teachers possessed some required skills in doing action research, still they lack most of the important skills in the conduct of action research. With this, an extensive faculty development program on action research must be developed, more avenues for teachers to be exposed to action research should be provided, taking their own research-based practice should be allowed, and their skills in doing action research should be enhanced. Furthermore, other mechanisms should be adopted by the schools such as the emphasis on doing participatory and collaborative action researches, support for more professional development programs, peer mentoring and advising, and other mechanisms that may be formalized and institutionalized.

Possible extension of this study is to extend its scope into other ethnic and cultural backgrounds since the scope of this study is only limited in the Philippines. This is to come up with a general conception of teachers on action research and their issues and difficulties across races, status, languages, and cultures.

\section{REFERENCES}

[1] Abaya, E. (2017). Situating action research in the institutionalization of culture of research and teacher agency. Presented during the National Conference on Research in Teacher Education. University of the Philippines.

[2] Arnold, I. J. (2008). Course level and the relationship between research productivity and teaching effectiveness. The Journal of Economic Education, 39(4), 307-321.

[3] Brookmyer, J. (2007). Findings from a survey of the CRESS Teacher Research Program. Windows on our classroom, 12, 123-133.

[4] Burns, A. (2011). Action research in the field of second language teaching and learning. Handbook of research in second language teaching and learning, 2, 237-253.

[5] Burns, D. (2014). Systemic action research: Changing system dynamics to support sustainable change. Action Research, 12(1), 3-18.

[6] Cain, T. (2011). Teachers' classroom-based action research. International Journal of Research \& Method in Education, 34(1), 3-16.

[7] Calhoun, E. F. (1994). How to use action research in the self-renewing school. Alexandria, VA: ASCD.

[8] Cardno, C., \& Piggot-Irvine, E. (1996). Incorporating action research in school senior management training. International Journal of Educational Management, 10(5), 19-24.

[9] Chen, X. B., \& Kessler, G. (2013). Action research tablets for informal language learning: Student usage and attitudes.

[10] Chen, Y., Nixon, M. R., Gupta, A., \& Hoshower, L. (2010). Research Productivity of Accounting Faculty: An Exploratory Study. American Journal of Business Education, 3(2), 101-115.

[11] Chevalier, J. M., \& Buckles, D. J. (2019). Participatory action research: Theory and methods for engaged inquiry. Routledge.

[12] Chou, C. H. (2011). Teachers' Professional Development: Investigating Teachers' Learning to Do Action Research in a Professional Learning Community. Asia-Pacific Education Researcher (De La Salle University Manila), 20(3).

[13] Clarke, P. A. J., \& Fournillier, J. B. (2012). Action research, pedagogy, and activity theory: Tools facilitating two instructors' interpretations of the professional development of four preservice teachers. Teaching and Teacher Education, 28(5), 649-660.

[14] Department of Education (2017). Action research. Retrieved from goo.gl/15dTsf.

[15] de Zeeuw, G. (2003). Helping others: Projects or research? Journal of Community and Applied Social Psychology, 13, 496-503.

[16] Dick, B. (2006). Action research literature 2004-2006: Themes and trends. Action research, 4(4), 439-458.

[17] Edwards-Groves, C., \& Kemmis, S. (2016). Pedagogy, 
Education and Praxis: understanding new forms of inter-subjectivity through action research and practice theory. Educational Action Research, 24(1), 77-96.

[18] Efron, S. E., \& Ravid, R. (2013). Action research in education: A practical guide. Guilford Press.

[19] Feldman, A., \& Weiss, T. (2010). Understanding change in teachers' ways of being through collaborative action research: A cultural-historical activity theory analysis. Educational action research, 18(1), 29-55.

[20] Halim, L., Buang, N. A., \& Meerah, T. S. (2010). Action research as instructional supervision: Impact on the professional development of university based supervisors and science student teachers. Procedia-Social and Behavioral Sciences, 2(2), 2868-2871.

[21] Hayes, G. R. (2011). The relationship of action research to human-computer interaction. ACM Transactions on Computer-Human Interaction (TOCHI), 18(3), 15.

[22] Hazelton, J., \& Haigh, M. (2010). Incorporating sustainability into accounting curricula: lessons learnt from an action research study. Accounting Education: an international journal, 19(1-2), 159-178.

[23] Hirsch, J.E. (2005). An Index to Quantify an Individual's Scientific Research Output. Proceedings of the National Academy of Science of the United States of America, 102(46), 16569- 16572

[24] Inanc, O. \& Tuncer, O. (2011). The effect of academic inbreeding on scientific effectiveness. Scientometrics, 88(3), 885-898

[25] Krell, D. E., \& Dana, N. F. (2012). Facilitating action research: a study of coaches, their experiences, and their reflections on leading teachers in the process of practitioner inquiry. Professional development in education, 38(5), 827-844.

[26] Kiley, M., \& Mullins, G. (2005). Supervisors' conceptions of research: What are they? Scandinavian Journal of Educational Research, 49(3), 245-262.3.

[27] Kusure, L. P., Mutanda, L., Mawere, D., \& Dhliwayo, L. (2006). Factors influencing research productivity among lectures in teachers' colleges in Zimbabwe. Southern Africa Journal of Education, Science and Technology, 1(2).

[28] Lewin, K. (1946). Action research and minority problems. Journal of social issues, 2(4), 34-46.

[29] Mamlok-Naaman, R., \& Eilks, I. (2012). Action research to promote chemistry teachers' professional developmentCases and experiences from Israel and Germany. International Journal of Mathematics and Science Education, 10(3), 581-610.

[30] Mapa, D. S. (2017). Research culture in the Philippines. Presented during the National Academy of Science and Technology, Philippines (NAST PHIL).

[31] Kemmis, S. \& McTaggart, R. (1988), The Action Research Planner. Geelong: Deakin University Press.

[32] Mc Kernan, J., (1991). Curriculum Action Research. A Handbook of Methods and Resources for the Reflective Practitioner London: Kogan Page
[33] McIntosh, P. (2010). Action research and reflective practice: Creative and visual methods to facilitate reflection and learning. Routledge.

[34] McNiff, J. (2016). You and your action research project. Routledge.

[35] McNiff, J. (1984). Personal and social education: A teacher's handbook. Hobsons Press (CRAC).

[36] Mertler, C. A. (2016). Action research: Improving schools and empowering educators. Sage Publications.

[37] Morales, M. P. E., Abulon, E. L. R., Soriano, P. R., David, A. P., Hermosisima, M. V. C., \& Gerundio, M. G. (2016). Examining teachers' conception of and needs on action research. Issues in Educational Research, 26(3), 464.

[38] Nolen, A. L., \& Putten, J. V. (2007). Action research in education: Addressing gaps in ethical principles and practices. Educational researcher, 36(7), 401-407.

[39] Ozer, E. J., Ritterman, M. L., \& Wanis, M. G. (2010). Participatory action research (PAR) in middle school: Opportunities, constraints, and key processes. American journal of community psychology, 46(1-2), 152-166.

[40] Riel, M. (2010). Understanding action research. Research Methods in the Social Sciences, 17(1), 89-96.

[41] Roleda, R., Tan, R., Culaba, A., Roleda, L., \& Bombongan, D. (2014). Academic linkages and research productivity. Presented during the DLSU Research Congress.

[42] Ross, J. A., \& Bruce, C. D. (2012). Evaluating the impact of collaborative action research on teachers: a quantitative approach. Teacher development, 16(4), 537-561.

[43] Salazar-Clemena, R. M. (2006). Higher education research in the Philippines: Policies, practices, and problems. In Higher Education, Research, and Knowledge in the Asia Pacific Region (pp. 185-200). Palgrave Macmillan US.

[44] Sales, A., Traver, J. A., \& García, R. (2011). Action research as a school-based strategy in intercultural professional development for teachers. Teaching and Teacher Education, 27(5), 911-919.

[45] Strambler, M. J., \& McKown, C. (2013). Promoting student engagement through evidence-based action research with teachers. Journal of Educational and Psychological Consultation, 23(2), 87-114.

[46] Stringer, E. T. (2008). Action research in education (2nd ed). New Jersey: Pearson

[47] Taylor, P. C., \& Medina, M. N. D. (2013). Educational research paradigms: From positivism to multi-paradigmatic. The Journal of Meaning-Centered Education, 1(2), 1-13.

[48] Tindowen, D. J. C., Bassig, J. M., \& Cagurangan, J.-A. (2017). Twenty-First-Century Skills of Alternative Learning System Learners. SAGE Open, 7(3).

[49] Ulla, M. B. (2018). Benefits and challenges of doing research: Experiences from Philippine public school teachers. Issues in Educational Research, 28(3), 797-810.

[50] Vinluan, L. R. (2011). Research productivity in education and psychology in the Philippines and comparison with ASEAN countries. Scientometrics, 91(1), 277-294. 
[51] Winch, C., Oancea, A., \& Orchard, J. (2015). The contribution of educational research to teachers' professional learning: Philosophical understandings. Oxford Review of Education, 41(2), 202-216.

[52] Ynalvez, M.A. \& Shrum, W.M. (2011). Professional networks, scientific collaboration, and publication productivity in resource-constrained research institutions in a developing country. Research Policy, 40, 204-216

[53] Zhou, J. (2012). Problems Teachers Face When Doing Action Research and Finding Possible Solutions: Three Cases. Chinese Education \& Society, 45(4), 68-80. 